\title{
Radical Rhetoric and the Working Class During Zimbabwean Nationalism's Dying Days ${ }^{1}$
}

Patrick Bond

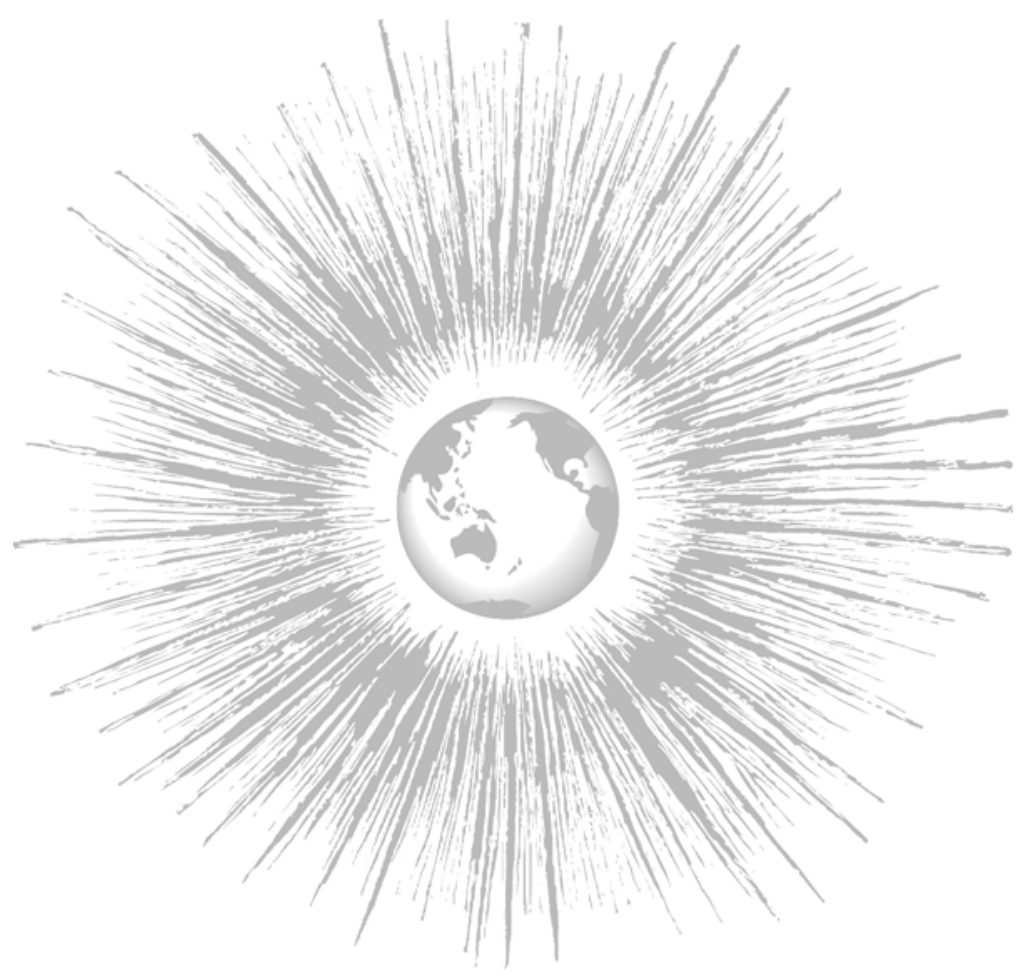

\section{INTRODUCTIONः AFRICAN NATIONALISM IN DECLINE}

tartling arguments have been made by radical scholars that the nation-state is no longer an appropriate site for contestation of formal power, on behalf of social progress, by the multitudes. ${ }^{2}$ Perhaps most extreme is the stance of Michael Hardt and Antonio Negri (2000: 305), in Empire:

As the concept of national sovereignty is losing its effectiveness, so too is the so-called autonomy of the political. Today a notion of politics as an independent sphere of the determination of consensus and a sphere of mediation among conflicting social forces has very little room to exist. Consensus is determined more significantly by economic factors, such as the equilibria of the trade balances and speculation on the value of currencies. Control over these movements is not in the hands of the political forces that are traditionally conceived as holding sovereignty, and consensus is determined not through the traditional political mechanisms but by other means. Government and politics come to be completely integrated into the system of transnational command. Controls are articulated

Patrick Bond

Graduate School of Public and Development Management

University of the Witwatersrand

Johannesbug

South Africa

pbond@wn.apc.org

http://pdm.mgmt.wits.ac.za/

1. Thanks are given to an anonymous JWSR reviewer, as well as to numerous Zimbabwean and South African commentators-especially Tawanda Mutasah and Peter Alexander-who provided feedback at a Rand Afrikaans University (Johannesburg) Department of Sociology seminar where this paper was first presented in mid-2000.

2. I review (and dispute) a few of the arguments for overarching attention to world-state building in Bond (1999b).

JOURNAL OF WORLD-SYSTEMS RESEARCH, VII, I, SPRING 200I, 52-89 
through a series of international bodies and functions. This is equally true for the mechanisms of political mediation, which really function through the categories of bureaucratic mediation and managerial sociology rather than through the traditional political categories of the mediation of conflicts and the reconciliation of class conflict. Politics does not disappear; what disappears is any notion of the autonomy of the political.

The decline of any autonomous political sphere signals the decline, too, of any independent space where revolution could emerge in the national political regime, or where social space could be transformed using the instruments of the state.

This deduction will be controversial, at least in the African semi-periphery and periphery. The approach taken in this essay is an investigation into political prospects within a single case, Zimbabwe, which embodies various discursive currents associated with African nationalism and class politics. Elsewhere (Mhone and Bond, forthcoming; Bond forthcoming-a), I discuss the material conditions required for Zimbabwe's 'national' economic revival, drawing upon a modified, partial 'delinking' scenario advocated by even the United Nations Development Programme.

Contrary to Hardt and Negri, I will conclude that the appropriate normative formula is not the dismissal of state-sovereignty as a short-medium term objective of Third World progressive social forces, but instead, aligned simultaneously with international popular struggles against the forces of Empire (both in Washington and transnational corporate headquarters), the rekindling of nation-state sovereignty but under fundamentally different assumptions about power relations and development objectives than during the nationalist epoch. Such power relations can probably only be changed sufficiently if the multitudes contest those comprador forces who run virtually all their nation-states. To do so, I submit, will require the articulation of a multifaceted post-nationalist political programme, grounded in post-neoliberal economic formulations.

Zimbabwe is obviously not the only situation in which to consider the challenge associated with this strategy, though it is certainly one of the crucial test-cases in coming months and years. If it is possible to generalise, the most exciting social struggles in contemporary Africa tend to be between advocates of progressive politics and basic-needs development within formal and informal organisationsbased in workforces, communities, women's and youth groups, environmental clubs and churches - on the one hand, and on the other, nationalist political parties that still rule most states, often pursuing neoliberal policies yet still capable of deploying radical rhetoric.

Representing the most advanced analytical and activist currents in the former camp, an 'African People's Consensus' backed by dozens of major grassroots advocacy/activist groups from Anglophone, Francophone and Lusophone Africa gathered momentum at a major conference in Dakar, Senegal in December 2000. ${ }^{3}$ Catalysed by traditional critiques of neoliberalism by African political-economists

3. The 'Dakar Manifesto: From Resistance to Alternatives' included the following argument:

...most of Africa's debt is odious, fraudulent and immoral. In fact, in most cases, debt has been contracted by not representative regimes that have used the amount received for purposes that have not served the interests of their peoples. Often, this debt served to consolidate and even legitimize dictatorships that used it to oppress their own people or to make war, with the benevolence and complicity of Western countries. Debt has also been contracted to undertake mega projects designed to stimulate exportations at the expense of the satisfaction of people's fundamental needs. The reimbursement of that debt is immoral: its service is diverting resources essential in the struggle against poverty, illiteracy and AIDS.

It's call for continental and regional coherence did not prevent a strong endorsement of Third World and international solidarity, or reassertion of the need for a revitalised state (though fundamentally different than that inherited from colonialism):

We will first attempt to strengthen the relationships between organizations committed to this struggle in Africa and in other developing countries as part of the Jubilee South movement. In fact, we think that the strengthening of such links constitutes one of the preconditions for the success of the campaign for debt cancellation. Solidarity between these organizations represents the base on which the solidarity between South and North organizations must be built. The strategic alliance with the latter constitutes a solid link in the chain of the world human solidarity for breaking the resistance and egoism of Western states and multilateral institutions...

Another development in Africa involves the creation of new development institutions, one of which is a new State ridden of its oppressive, exploitative and repressive colonial heritage. In fact, it is imperative to reconsider all institutions inherited from colonization and create instead new institutions consistent with an endogenous and autonomous approach to development. The State and most present institutions are of 'elitist' type and carbon copies of their European counterparts. That is why they participate more in the repression and exploitation of the African people than in the creation of conditions allowing them to develop all their potential and to blossom. In fact, institutions created to enslave Africans would not, under any circumstances, serve to free them. Therefore, new institutions whose nature and functions are different from the ones inherited from colonization, are needed. It is necessary to put in place a new State, which will ensure equity between all and promote an integrated human development.

Organisers included CONGAD (Le Conseil des Organisations Non-Gouvernementales d'Appui au Developpement; http://www1.telecomplus.sn/cig/congad) in Senegal; Jubilee South http://www.jubileesouth.net, the Committee for the Cancellation of Third World Debt (COCAD/CADTM: http://users.skynet.be/cadtm), and the Centre National de Cooperation au Developpement. 
like Samir Amin (who gave the main plenary talk in Dakar), ${ }^{4}$ this perspective is encouragingly similar to the kinds of international anti-capitalist, people-centreddevelopment' discourses offered by the popular movements across the world, that have generated such upsurges of protest in many sites over the past few years, including Africa, on matters such as debt $t^{5}$ and trade. ${ }^{6}$

Africa's crises-encompassing socio-economy, geopolitics, ethnicity, public health, ecology, gender relations, youth and many other sites of conflict-have

4. Others in the tradition include Fantu Cheru, Guy Mhone, Thandika Mkandawire, Dani Nabudere and Bade Onimode.

5. Not atypical of the discourse was this comment from the conference (in Lusaka in May 1999) which launched the African People's Consensus process (with delegates representing debt campaigning groups from Burkina Faso, Lesotho, Kenya, Malawi, Mozambique, Nigeria, Cameroon, Swaziland, Tanzania, Togo, Uganda, South Africa, Zambia and Zimbabwe):

We insist that debt is a manifestation of the neoliberal world order, the power of international banks to push loans on Southern borrowers without the democratic inputs of parliaments and civil societies, and the disastrous character of the world economy, which charges ever greater prices for imports from the North while paying ever lower prices for Southern exports. In short, debt is one of the most important instruments of Northern domination over the South and the domination of financiers over people, production and nature everywhere. (for more see http://aidc.org.za)

6. Also emblematic of the radical rhetoric of some civil society networks on trade (e.g., the Africa Trade and Development Network), a 'Southern African Peoples Solidarity Network' meeting paralleled the Windhoek (Namibia) summit of the Southern African Development Community (in August 2000), and resolved that the governments of our countries'

- have for long mainly engaged in rhetorical declarations about national development, and development cooperation and regional integration, with few effective achievements;

- are mainly concerned with preserving and promoting their own individual and group status, power and privileges, and their personal and aspirant-class appropriation of our nations' resources; and, for these reasons, are frequently engaged in divisive competition and even dangerous conflicts amongst themselves at the expense of the interests of the people at national and regional levels;

- are, at the same time, committed to supporting and defending each other whenever the interests and power of the ruling elites come into conflict with the human rights, and the democratic and development aspirations of their own populations; and are using SADC as a self-serving 'old boys' club' for such mutual support;

- are increasingly responsive and subordinate to external inducements and pressures from governmental agencies in the richest industrialised countries, and their global corporations, banks and other financial organisations, and the 'multilateral' institutions dominated and used by them. $\underline{\text { http://aidc.org.za }}$ generated widespread despair about the continent's condition, especially from paternalistic Northern critics. ${ }^{7}$ The period of Afropessimism, which continues, requires the fading from memory of the accomplishments of 1950s-90s struggles for national/racial justice. Only in newly liberated sites (South Africa, Namibia, Eritrea) and in last-gasp resurrections (Zimbabwe, as this essay dwells upon) does 'nationalism' retain substantial purchase.

Yet in virtually all the continent's anti-colonial projects during the last half of the 20th century could be found liberatory rhetorics: of human dignity that a fullyfledged citizenship would provide at Independence, of the simultaneous need to capture the state and nurture participatory democracy, of socialist (or at the least Uhuru) development ideals, of ending racial (and sometimes gender) oppression, and of the harmonious relations between states and civil societies that would make these visions a reality. The late Claude Ake (2000:46) expressed it as follows:

The language of the nationalist movement was the language of democracy, as is clear from: I Speak of Freedom (Nyerere), Without Bitterness (Orizu), Facing Mount Kenya (Kenyatta), Not Yet Uhuru (Odinga), Freedom and Development (Nyerere), African Socialism (Senghor), and The Wretched of the Earth (Fanon). It denounced the violation of dignity of the colonised, the denial of basic rights, the political disenfranchisement of the colonised, racial discrimination, lack of equal opportunity and equal access, and economic exploitation of the colonised. The people were mobilised according to these grievances and expectations of a more democratic dispensation.

Of course, things went badly wrong in virtually all cases. In some ways, the malgovernance that emerged across Africa emblematised larger political-economic processes and geopolitical alignments associated with the Cold War-whose African battlegrounds were often extremely hot-and the simultaneous slowdown in economic growth (and hence demand for raw materials) in Northern sites of industrial accumulation. These factors culminated in a global political-economic environment that, during the last two decades of the $20^{\text {th }}$ century, was not conducive to African development.

Internal reasons for Africa's economic problems vary, but included inherited colonial legacies (including the illogicality of many borders) and the transition from colonialism to undemocratic (and often corrupt), highly-militarised neo-colonial regimes. Many had adopted economic strategies which benefited a few urban elites at the expense of peasants (especially women producers), workers and even local

Exemplary of banal, victim-blaming argumentation is The Economist, 13 May 2000, whose cover story on 'The Hopeless Continent' is subtitled: Africa's biggest problems stem from its present leaders. But they were created by African society and history.' 
manufacturers. The continent's civil wars and adverse climatic conditions (droughts and floods) are increasingly identified with structural political-economic problems, ranging from post-Cold War geopolitical fragility to global warming. But too, domestic economic policies, especially in the main settler-colonial societies, were often inappropriate (Import Substitution Industrialisation was biased towards luxury-goods production, which ironically caused even greater dependence upon external sources of sophisticated machinery, parts and raw materials). Subsequent export-led growth strategies were typically promoted as a central component of 'macroeconomic reforms' imposed on countries by lenders and Northern governments, notwithstanding the declining, glutted character of world markets associated with the main goods produced in Southern Africa.

In virtually no cases, in Africa or elsewhere, were power relations optimal to develop an economy from the standpoint of meeting the basic needs of all in society, even though this kind of strategy would have provided far greater 'multipliers' (economic spin-offs) than multinational corporate investments or African post-colonial rulers' own prestige projects (see, e.g., Wisner, 1991). But aside from Cold War military and political interference, there were, moreover, two main external factors associated with Africa's economic crisis: falling international commodity prices since the mid-1970s (the drop for non-oil commodities was more than 80\% from 1973 to 1993), and rising real interest rates since 1979 applied to massive, growing external debt (the real dollar-denominated effect was from -4 to $4 \%$ ). The treadmill ran everfaster, leaving virtually all of Africa with a reduced capacity to raise foreign exchange simultaneous to a rise in annual debt servicing obligations to levels typically above $25 \%$ of forex income.

Even taking this macroeconomic bind as given, a material link to the African crisis must also be identified at lower levels, in the rural settings in which African nationalism has proven most durable. Indeed, Mahmood Mamdani (1996: 111) argues that much of Africa's local-level rural state administration amountedthanks to nationalist appropriation of colonial mechanisms-to decentralised despotism,' even prior to the 1980s-90s crisis. Virtually all attempts to reform colonial-era Native Authority (and equivalent ethnic-based) systems in Africa failed. Even under the best case, Museveni's Uganda, where local-level power relations inherited from centralised-despotic rule had to be thoroughly broken, there remained a 'bifurcated' duality of power: between a centrally-located modern state (sometimes directly responsible for urban order in primate capital cities) and a 'tribal authority which dispensed customary law to those living within the territory of the tribe.'

With this observation, Mamdani (1996: 287) sets the stage for the problem of global-national-local processes:
In the absence of democratisation, development became a top-down agenda enforced on the peasantry. Without thorough-going democratisation, there could be no development of a home market. The latter failure opened wide what was a crevice at Independence. With every downturn in the international economy, the crevice turned into an opportunity for an externally defined structural adjustment that combined a narrowly defined programme of privatisation with a broadly defined programme of globalisation.

The implications of this combined failure of the African state-in overlaying neoliberalism upon often-despotic rural social control—can be understood in Zimbabwe. There, not only has the existing urban-rural divide opened extremely wide in recent years. In addition, as we see, a broader (urban-based) challenge to political order has, since the late 1990s, generated more acute responses than in most countries. And here arises the dubious challenge posed by Hardt and Negri (2000: 43), to do away with any nostalgia for the power structures that preceded [Empire] and refuse any political strategy that involves returning to that old arrangement, such as trying to resurrect the nation-state to protect against global capital,' because 'we insist on asserting that the construction of Empire is a step forward in order to do away with any nostalgia for the power structures that preceded it.'

Thus, in a seeming reversal of the 1960s 'winds of change' remarked upon by British premier Macmillan while liquidating the formal British empire, the surfacelevel appearance of Zimbabwe's 2000 parliamentary campaign had all the hallmarks of a young, fresh, democratic, and pro-Western wind sweeping out Zimbabwe's oldfashioned, proto-Stalinist 'socialist' rulers. President Robert Mugabe's reaction to a new opposition party's dramatic rise in popularity, after all, occasioned a renewed round of bashing a few thousand white farmers and the International Monetary Fund. As portrayed by the mainstream media to most of the world, Zimbabwean nationalism was in its dying days, as new, popular, democratic and ostensibly market-oriented politicians - led by two modern trade unionists - prepared to sort out the mismanagement, end the corruption and reverse the ruling party's incompetent left-wing economic policies.

But matters are certainly not that clear, and to understand why Mugabe's Zimbabwe African National Union-Patriotic Front (Zanu PF) isn't by any means the 'Left' or even 'progressive' social force in Zimbabwe, requires looking first at the post-independence socio-economic record, and then the contestation between leftwing and rightwing tendencies within the trade union movement and opposition party. The logic of the argument should be clear: the rhetoric of nationalism in disguising the exhaustion of a capital accumulation cycle itself becomes delegitimised; yet in this context, as a new working-class ideology struggles to emerge, the residual power of left-sounding discourses within nationalist rhetoric retains great currency. This is the source of Zimbabwe's terrible contemporary confusion. While 
resolving the confusion through intensified class struggle remains vitally important, that struggle is more likely in the short term to be prosecuted by the international, regional and domestic capitalist classes, via IMF policy dictates, accommodated by Zanu PF (with the support of some influential 'left-nationalist' intellectuals) even if Mugabe implements the 'necessary' stabilisation measures apparently kicking and screaming. Radicals in Zimbabwe's growing social movements have an enormously difficult period immediately ahead.

\section{STRESSED NATIONALISM}

Under the circumstances, it is easy to see why Zimbabwe's nationalist project is exhausted, a phenomenon widely understood throughout society at the point its rule reached two decades in duration, in 2000. One sign, early that year, was the electorate's rejection of a referendum promoted heavily by the Zanu PF government. In desperation, Mugabe resurrected Zanu PF's most militant, often virulent strain of nationalist demagoguery, attempting as time ran out to simultaneously solve' the long-standing land distribution problem, terrorise supporters of the opposition, and pass the buck for its own failings to, variously, the country's small white population, foreign countries (especially Britain and the US), imperialism in general and the International Monetary Fund (IMF) in particular.

Separating the truth from the myth-making in Zanu PF's repertoire is important. But it goes without saying that for the foreseeable future, Zimbabwe will remain in 'crisis' - a situation whereby socio-economic equilibrating mechanisms have broken down, and some force external to the prevailing systematic logic must be invoked to restore stability. We return to this definition at the conclusion, for it implies the need for a much more radical process of social change than even the country's recent upsurge of working-class and nationalist rhetorics suggest. And for many such African - and other Third World - countries facing the depredations of exhausted nationalism, the challenge of countering radical rhetoric with discourses that attract voters, and also conservative economic argumentation to attract the 'international community' can be debilitating.

In such a context, the contestation of political rhetoric and reality remains profound. The potential for violence and terror in such a process was already witnessed before the June 2000 parliamentary elections, when more than three dozen murders were amongst 5,000 recorded incidents of state-sanctioned intimidation. At surface level, sites of crisis in early 2001 include a massive fiscal deficit that had worsened dramatically in 2000 as Mugabe's election-patronage strategy unfolded. The country is periodically hampered by foreign exchange shortages, with the normal six months of import cover reduced to a few days' worth. Both city and countryside are vexed by periodic fuel scarcity that began in late 1999, with no end in sight. The army is overcommitted in a hopeless war, with more than 10,000 troops deployed far away in the Democratic Republic of Congo, in part to guard the diamond mines of leading Zimbabwean politicians and generals (the quid pro quo that the late Laurent Kabila offered Mugabe for the military support required to defend key installations against rebel groups backed by Uganda and Rwanda). Zimbabweans grieve lost family and friends in the midst of the AIDS pandemic, with more than one in five adults now HIV positive. The economy has, since the early 1990s, suffered unprecedented price inflation (higher than 60\% in 2000), as business failures and unemployment soared from the outset of the latest downturn in late 1997. Policy confrontations with the IMF and World Bank continue. Income inequality rose during the 1990s to amongst the world's worst levels, especially with respect to control of good farming land. Rife with corruption, the Zanu PF government appears to be in death-throes stage, with internecine conflict between old-and new-guards often exploding into public (and degenerating into chaos in several of the party's provincial structures), and likely to worsen prior to the next presidential election (mid-2002) in which Mugabe may or may not choose his successor. The country's 12 million people are restless and often furious, as demonstrated in occasional urban riots.

However, these symptoms are rarely explored in relation to the underlying character of the struggle, confused as it is by ideological fudging. The 2000 election did not clarify much, with Zanu PF taking $48 \%$ of 2.5 million votes, against $46 \%$ for the opposition Movement for Democratic Change (MDC), a difference of just 70,000. Zanu PF thus gained 62 of 120 contested seats, with an additional 30 appointed directly by Mugabe according to an outmoded, unpopular constitution. A few months earlier, in February, a national referendum on a new constitution55-45\% against government proposals-had revealed an impressive mobilisation of MDC supporters and an apathetic turnout from peasants who normally champion the ruling Zanu PF party. If the referendum was widely interpreted as another 'yellow card' (soccer referee warning) for Mugabe, the MDC hopes and plans on using its 'red card' (eviction) emblem in the 2002 presidential election, under the leadership of a charismatic ex-trade unionist, Morgan Tsvangirai.

Mugabe, 76, has raised hopes, even within Zanu PF (which correctly sees him as a popular liability) by hinting that he won't stand again. But at this writing it appears he may well run for a fifth term as leader, as there is no obvious successor in the wings of his fractious, crisis-ridden party. A December 2000 Zanu PF congress rid the leadership of at least one potential successor (a lawyer, Eddison Zvobgo), thanks to Mugabe-authorised purges. Former minister of justice Emmerson Mnangagwa, who in the 2000 election lost his constituency seat to the MDC, was brought back by Mugabe to become Speaker of Parliament, and is usually mentioned as a logical heir, as is Zanu PF chairperson John Nkomo (from the Ndebele ethnic minority, which probably prevents him becoming national 
leader). But an additional name, Simba Makoni, a much younger (51) technocratpolitician recently named as finance minister, has also surfaced as the possible heir. Ironically, the most influential advisor to Mugabe has been Zanu PF's minister of information Jonathan Moyo, a former liberal political scientist (trained at University of Southern California) who during the 1990s directed the Ford Foundation in Kenya but who turned to hard-line nationalist discourses in 1999 (Moyo has many internal foes in Zanu PF, but remains a significant personality, known for untiring vitriol against opponents). Regardless of which individual is given the status of presidential candidate (and when that might happen), the job of controlling a fracture-ridden party - and from there, the fortunes of the country-will still likely be Mugabe's for the foreseeable future (as it was Julius Nyerere's in the Tanzanian ruling party during the 1980s following his formal retirement from government). In short, however, the role of leading personalities during a period of ebbing African nationalism is often decisive, warranting continuing attention.

The most likely scenario, then, is that Mugabe retains his office until the last minute, dispensing patronage and probably terror in equal measure, hoping to assure some kind of amnesty for crimes he could be prosecuted for-whether associated with corruption or his role in the mid-1980s mass murder of 5,000 Ndebele civilians in Matabeleland. MDC leader Tsvangirai publicly offered such an amnesty in early 2000, when it appeared his party would win the parliament convincingly; Mugabe turned instead to a campaign of intimidation and squeaked through the election with a bare majority of contested seats.

Still, the MDC gained powerful experience and momentum in the June 2000 elections. It has the capacity to harass Mugabe through its 57-strong parliamentary delegation (such as through a presidential impeachment process which amounts mainly to a public relations gimmick) and various legal challenges to the ruling party. ${ }^{8}$ Thus, the widespread impression in Zimbabwe is that even a dynamic Zanu $\mathrm{PF}$ leader with full party support will not prevent a transfer of executive power in 2002.

Yet, cynics posit, Tsvangirai will just as likely repeat the wretched experience of Zambia. There, trade unionist Frederick Chiluba won the 1991 election against veteran nationalist Kenneth Kaunda with a multiclass alliance, and quickly applied neoliberal economic policy with even worse results than his predecessor. Unpacking

8. The merits of such approaches, in contrast to mass-action strategies in the streets, was thrown into question repeatedly, including in a failed MDC effort to contest 39 of the parliamentary contests it lost, as Zanu PF then legislated in parliament that any such challenge was illegal. the ideological 'spaghetti' (as Tsvangirai terms it) of the MDC's self-styled 'social democracy' is thus a vital ongoing exercise. Given that the MDC is the first political party over the past two decades with a chance of upsetting Zanu PF's hold on power, the run-up to 2002 presents a crucial time for defining the ideological struggles within the struggle. To do so requires reconsideration of the 1990 s socioeconomic crisis.

\section{THE LOST DECADE OF STRUCTURAL ADJUSTMENT}

In 1980, Zimbabwe's independence was won after a brutal war against 200,000 white, settler-colonial Rhodesians (with 40,000 black casualties); the core force was a guerrilla army which enjoyed — and sometimes forcibly compelled—mass support from the peasantry. Mugabe and his on-off-on ally Joshua Nkomo (who died in 1999) established an ideology of national unity with 'socialist' overtones. But over the years Zanu PF's status quo development strategy failed to raise living standards, aside from construction of an initial round of rural clinics and schools, and the growth of a 180,000-strong lower middle-class state bureaucracy.

A key reason was the growing influence of the World Bank and IMF. While the 1990s represent a lost decade of development for Zimbabwe, the rot had set in earlier. Even in 1977, political scientist Rukudzo Murapa predicted ruptures within the alliance between 'a politically ambitious petit-bourgeois leadership, a dependent and desperate proletariat and a brutally exploited and basically uninitiated peasantry.' Forecast Murapa (1977: 28),

After national liberation, the petitbourgeois leadership can abandon its alliance with the workers and peasants and emerge as the new ruling class by gaining certain concessions from both foreign and local capital and, in fact, forming a new alliance with these forces which they will need to stay in power. Of course, lip service commitment, a la Kenya, to the masses, will be made.

Zanu PF leaders' post-independence realignment is reflected not only by the steady rise in corruption, and by the fact that most of the good agricultural land and other wealth redistributed since 1980 has gone to Mugabe cronies, not the masses. Most importantly, Zimbabwe's new rulers made bad policy choices and succumbed to arm twisting by Washington. Finance minister Bernard Chidzero (who later chaired the IMF/Bank Development Committee) borrowed massively at the outset, figuring that repayments-which required $16 \%$ of export earnings in 1983-would, he insisted, 'decline sharply until we estimate it will be about 4\% within the next few years. ${ }^{9}$ The main lender, the World Bank (1992: 3), concurred:

\footnotetext{
9. Herald, 22 February 1983 ,
} 
'The debt service ratios should begin to decline after 1984 even with large amounts of additional external borrowing.' In reality, Zimbabwe's debt servicing spiraled up to an untenable $37 \%$ of export earnings by 1987.

Loan conditions quickly emerged. By 1985, the IMF pressured Mugabe to cut education spending, and in 1986 food subsidies fell to two-thirds of 1981 levels. Similarly, genuine land reform was stymied not only by the 'willing-seller, willingbuyer' compromise with Ian Smith's Rhodesians during the 1979 constitution-writing exercise at Lancaster House, but by the World Bank's alternative: showering peasants with unaffordable micro-loans. From a tiny base in 1980, the Bank's main partner agency in Zimbabwe granted 94,000 loans by 1987. But without structural change in agricultural markets, the Bank strategy floundered, as $80 \%$ of borrowers defaulted in 1988 notwithstanding good rains (Bond, 1998: Chapter 10).

Radical analyst Ibbo Mandaza (1986: 53) lamented, 'International finance capital has, since the Lancaster House Agreement, been the major factor in the internal and external policies of the state in Zimbabwe.' Agreed Thandike Mkandawire (1984: 43), presently head of the Geneva-based United Nations Research Institute for Social Development, 'It seems the government was too anxious to establish its credentials with the financial world.'

The macroeconomic situation worsened when Chidzero persuaded Mugabe to ditch Rhodesian-era regulatory controls on prices and foreign trade/financial flows, liberalising the economy through an Economic Structural Adjustment Programme (Esap) in 1991. Esap was supposedly 'homegrown,' but World Bank staff drafted much of the document, which was substantively identical to those imposed across Africa during the 1980s-90s.

Esap brought immediate, unprecedented increases in interest rates and inflation, which were exacerbated (but not caused) by droughts in 1992 and 1995. As money drained from the country, the stock market plummeted by $65 \%$ in late 1991 and manufacturing output declined dramatically (from a peak 32\% share of GDP in 1992 to 17\% six years later). From 1992 to 1994 alone, Zimbabwe's largest textile firm and more than 60 clothing firms collapsed, and the industry that remained operated at only 65\% capacity in 1995 (Zimbabwe Congress of Trade Unions, 1996: 48). The country became little more than a re-export platform for South and East Asian textiles (technically dumped') and second-hand clothes from European aid agencies. Ironically, against all evidence to the contrary, the World Bank's Project Completion Report (1995: 23) gave the best possible final grade to Esap: 'highly satisfactory' All the macroeconomic targets failed, but the Bank blamed 'poor phasing' and two droughts.

Urban workers and lumpenproletarians began to resist, most self-destructively in a series of 'IMF Riots' during the 1990s, and also less obviously through a dramatic rise in petty crime and domestic violence. More promisingly, the 1990s saw the emergence of a deep-rooted urban political alienation from nationalist discourse, and the rapid maturing of political consciousness. At the beginning of the 1990s, the Zimbabwe Congress of Trade Unions (ZCTU) under Tsvangirai's leadership broke out of a paternalist grip in which Zanu PF had held the federation since its 1981 founding (when Albert Mugabe, brother of Robert, served as secretary), and in which union strategies, tactics and politics were controlled during the 1980s. As general secretary in 1989, Tsvangirai even found himself in jail for two weeks, simply for supporting left-wing students' criticism of Zanu PF's rapid right-wing drift towards structural adjustment.

Quickly identifying neoliberalism as one of the most important issues (along with corruption) dividing the Zimbabwe government from the masses, Tsvangirai predicted a difficult period ahead, at the outset of the Esap when bourgeois commentary was universally optimistic:

What we are looking for in Zimbabwe is a democratic space. Because what is going to be sacrificed in this programme [Esap] is democracy. When people go to the streets, complaining about these things, the state will be forced to use power to quell these riots, and in fact one of the ironies is that we are arming our own people - the police and the army - to turn against our people....At the end of the day we become the marginalised group, because the government has put itself in a position so that it cannot take a stand against the IMF. The only way to defend against international capital marginalising further the indigenous businessman, the worker, the peasant, is to have all these groups together. ${ }^{10}$

Yet the ZCTU was not well-placed to take advantage of the opening, and instead zigzagged between anti-imperialist critique of externally-imposed structural adjustment (1990-94), a desire for corporatist technical solutions (1994-97) and a broad-based front-building strategy aimed at dislodging the authoritarian Zanu PF regime (1997-present) (Raftopoulos and Sachinkonye forthcoming; and Yeros forthcoming). The erratic nature of ZCTU politics can probably best be explained by the movement's initial political marginalisation, for the Zanu PF government's divide-and-conquer strategy (enhanced by residual nationalist loyalties in several key union affiliates) seriously threatened the ZCTU after an initial anti-Esap union protest on May Day, 1992 was met with repression. As the ZCTU retreated into an aspirant-corporatist mode, even Tsvangirai sought an accommodation with neoliberalism.

10. Author's interview with Morgan Tsvangirai, published as 'What We Need is Mass Action!,' Southern Africa Report, July 1991. 
To this end the ZCTU's important 1996 Beyond Esap policy advocacy document was penned by a diverse group of technical associates (including one noticeable merchant banker). Blinkered by the desire to remain relevant to reforming Esap in potential tripartite settings (including sectoral fora dealing with housing, social security and other social policies), Beyond Esap in fact codified many of the Mugabe regime's worst conceptual errors and policy recommendations. As Tsvangirai himself wrote in the foreword, 'While acknowledging that SAPs are necessary, the study shows that they are insufficient in fostering development' (a more militant political strategy would have generated the affirmation that Esap was unnecessary and indeed that it fostered underdevelopment in Zimbabwe during the 1990s).

The ZCTU's (1996: i, 20-21, 58, 61) neoliberal policy concessions in Beyond Esap included (1) avoiding 'subsidisation of nonproductive uses'; (2) means-testing 'welfare and relief funds'; (3) 'trimming the public sector'; (4) 'repeal [ing] any regulations... that discriminate against non-formal sector activities or small-scale firms'; (5) 'hav[ing] the peasant captured by the market'; and (6) 'close government collaboration with private business' on industrial policy. Beyond Esap also suggested that 'financial resource mobilisation' should include 'government selling off its assets using the proceeds to reduce the stock of debt' and 'encourag[ing] people to save by providing incentives that would encourage them to invest in shares quoted on the Zimbabwe Stock Exchange.' Regarding fiscal policy, the ZCTU consultants argued, 'current [domestic] debt needs to be reduced substantially' and there is a 'need to redirect government funds away from recurrent towards capital expenditure.' The ZCTU also posed a crucial limitation for future strategies, namely that 'There can be no return to pre-Esap policies, partly because of the stranglehold that foreign creditors have on policy through the substantial debt that has accumulated, paradoxically, because of the failure of the policy. ${ }^{11}$

The basis for the terribly concessionary language - a reflection of the opposition's lost decade, in programmatic terms-was a consistent, mainly fruitless attempt to establish a broad 'social contract' that would, as Tsvangirai put it in a typical mid-1990s remark,

involve the three parties reaching a consensus where workers agree to restrain wage demands on the one hand and employers agree to control price increases for commodities, invest surpluses to create more jobs and train workers on the other. For Government, you would expect them to cut spending. ${ }^{12}$

\footnotetext{
11. See Bond 1998: Chapter 12, for full details.
}

12. Cited in Sachikonye, 1998: 127.

\section{THE RESURGENCE OF 'LEFT' RHETORIC}

Corporatism on the semi-periphery of the world economy is never easy. As Zimbabwe's economic crisis deepened, autonomous, shopfloor-based actions outran the ability of national union bureaucrats to control or direct the membership. The corporatist strategy mistakenly pursued during the mid-1990s by the ZCTU quickly became irrelevant.

By 1998, in the wake of an unprecedented year-long wave of worker militancy (including previously docile public sector employees and even atomised plantation workers) and two successful national mass strikes against Mugabe's policies, Tsvangirai had changed direction again, this time apparently back to the left. Instead of joining a National Economic Consultative Forum in January 1999, as expected, he led a ZCTU walkout on the grounds that Mugabe's government could not be trusted. A few weeks later, Tsvangirai convened a broad-based National Working People's Convention (a significant name), which cited not only good-governance concerns, but also

the inability of the economy to address the basic needs of the majority of Zimbabweans; the severe decline in incomes, employment, health, food security and well being of people; the unfair burden borne by working women and persistence of gender discrimination in practice; the decline, and in some cases collapse of public services; the lack of progress in resolving land hunger and rural investment needs; the weak growth in industry and marginalisation of the vast majority of the nation's entrepreneur's...

\section{In contrast, the Convention resolved that}

National policies should prioritise the mobilisation and organisation of resources to meet people's basic needs for food security, shelter, clean water, health and education; the equitable distribution of resources such as land, skills, capital and technology for production and industrialisation strategies that are based on building and using the capabilities of the people for production.... The country should aim to reduce its dependency on foreign loans and the loss of sovereignty that this brings.... The right to a minimum standard of health inputs (food, water, shelter) and health care must be defined and entrenched in the constitution, guaranteed and funded on an equitable basis by the state through its mobilisation of national resources.... The Convention thus resolved to take these issues to the people across the country, to mobilise them towards the working people's agenda, and to implement a vigorous and democratic political movement for change. ${ }^{13}$

\footnotetext{
13. http://www.samara.co.zw/zctu/position.htm
} 
Tsvangirai also led a National Constitutional Assembly process that in 1998-99 garnered sufficient popular support to force Mugabe to set up his own constitution-rewriting commission. And in a telling move, he explicitly-if unsuccessfully - informed the IMF that any further funding to the Zanu PF government in August 1999 would be firmly opposed. The massive foreign debt Zimbabwe faces will be a bone of contention for any post-Mugabe government, and questioning the legitimacy of structural adjustment funding to Mugabe was an important first step towards, potentially, repudiating the IMF and Bank's other loans at some future date. Finally, when in mid-1999, ZCTU leaders Tsvangirai and Gibson Sibanda (the federation's president) announced the formation of the 'labour-backed' MDC, a founding manifesto balanced its overall good governance orientation with quite expansive socio-economic visions. ${ }^{14}$

Interestingly, at the MDC's launch in September 1999, Sibanda attempted to undermine Zanu PF's claim to nationalist memory by describing the new democratic struggle as another 'chimurenga' war, in the same spirit as a 1890s insurrection against the initial white-settler invasion, and the 1960s-70s guerrilla war against Rhodesian colonialism:

Our struggle in Zimbabwe has always been a struggle for the dignity and sovereignty of the people. We, the workers and peasants have always been in the leadership of that struggle, In our first chimurenga/umvukela, workers fought against massive exploitation in the mines, farms and industry, and peasants against the expropriation of their land. The nationalist and liberation movement that led the second chimurenga/umvukela was born from and built on the struggles of workers and peasants. But after twenty years of Independence, we now have a ruling nationalist elite that has exploited this long history towards its own ends, betraying the people's struggles. Is this the country that we fought for and rejoiced in $1980 ?^{15}$

A few months later, Tsvangirai provided more clarity about the potentially postnationalist, post-neoliberal MDC project:

In many ways, we are moving from the nationalist paradigm to politics grounded in civic society and social movements. It's like the role and influence that in South Africa, the labour movement and civil society organisations had over the African National Congress in the early 1990s. MDC politics are not nationalist inspired, because they focus more on empowerment and participation of the people. Zanu PF's nationalist thinking has always been top-down, centralised, always trapped

14. http://www.mdc.co.zw/intro-frames.html

15. The Worker, 72, September/October 1999; for more on the ideological give and take, see Yeros, forthcoming. in a timewarp. Nationalism was an end in itself instead of a means to an end. One of Zanu PF's constant claims is that everyone in Zimbabwe owes the nationalist movement our freedom. It's therefore also become a nationalism based on patronage and cronyism. ${ }^{16}$

For 'Tsvangirai, a logical discourse was 'social democracy':

We are social democrats. The MDC can never be pure, ideologically, because of our broad orientation. Besides, social democracy is a half-way house, a spaghetti mix. In our case, the main characteristic is that we are driven by working class interests, with the poor having more space to play a role than they do now. But one of the components is an element of participation by business, which is just not able to develop under present conditions.

In slightly more concrete terms, the implications involve a strong commitment to meeting basic needs:

Development must be genuine, defined by people themselves. We know that export-led growth is not a panacea. And we place a high priority on meeting basic needs. How could we not, with $75 \%$ of the population live below poverty? So our development strategy will highlight land, health, education and the like.

When asked of the concern that with such a multi-class project, the MDC will end up like the Zambian Movement for Multiparty Democracy, Tsvangirai replies:

I think Chiluba did not come on board with any ideology at all. But the main lesson there is that if the workers are not careful, they may give up their initiative over the party. That means that even though we need to build coalitions, the structure of MDC has to be, and is, participatory, with far more control from the base than normal parties.

The best indication of the potential for Zimbabwe workers' leftward momentum, in the wake of the conservative discourses of the 1990s, may simply be Mugabe's own confused and confusing reaction: a resurgence of leftwing rhetoric. By late 1999, Mugabe publicly told the IMF to 'Shut up!', amongst other outbursts reported in the international press. This was not unjustifiable, for the IMF's Zimbabwe objectives were straightforward: Mugabe was told in August 1998 to reverse the only three progressive things he had done in a long time, namely the imposition of a) a ban on holding foreign exchange accounts in local banks, b) a luxury import tax in 1997, and c) of price controls on staple foods in mid-1998 in the wake of IMF riots. Corporate foreign currency accounts were reintroduced (with a small amount withheld to pay for vital inputs), and so, according to a blunt Michael Nowak, IMF assistant director for Africa,

\footnotetext{
16. See Southern Africa Report, 15, 3, June 2000, for these and the following quotes.
} 
There are two issues outstanding and these have stopped the IMF from making the [ $\$ 53$ million] standby credit available to the country. These issues are, one, we want the government to reduce the tariffs slapped on luxury goods last September, and secondly, we also want the government to give us a clear timetable as to when and how they will remove the price controls they have imposed on some goods. ${ }^{17}$

Mugabe gave in sufficiently to win the first tranche of support in August 1999, but when he continued running a budget deficit and refused to unpeg the Zimbabwe dollar from the US dollar, ${ }^{18}$ the IMF quickly stopped the funds. Holders of forex accounts began hoarding hard currency, and by late in 1999 Zimbabwe ran out of foreign reserves and, in turn, could not even pay for US\$10 million in monthly petrol imports.

The issue of Zimbabwe's sovereignty persisted, as shown below, into campaign debates over the government's 'Millennium Economic Recovery Programme' (a slightly more dirigiste structural adjustment programme). Yet even if Mugabe was appropriately furious at IMF bias against the poor, again and again, throughout Zimbabwe's history, the president had shown a remarkable capacity to 'talk-left, act-right.' Mugabe often reserved his most revolutionary-sounding rhetoric for those occasions when there appeared leftwing political threats. As a US banker observed in 1982, 'I feel it is a political pattern that Mugabe gives radical, antibusiness speeches before government makes pro-business decisions or announcements. ${ }^{19}$

The most emotive 'anti-business' issue in Mugabe's contemporary discourse is land inequality, and with it, the violation of property rights. (Such violation is, by all objective considerations, required to resolve the problem, given the failure of willing-seller/willing-buyer policy over two decades duration.) Yet here Mugabe has potentially broken the talk-left, act-right mould. In 1997 Mugabe restored the prominence of the War Veterans' Association, after a long period of neglect. He granted each vet $Z \$ 50,000$ (then US\$5,500) on a once-off basis, plus a $Z \$ 2,000$ pension per month. The vets, in turn, became Mugabe's shock troops after the February 2000 referendum defeat, invading more than 1,500 white-owned farms, and allowing Mugabe to resurrect, yet again, the claim that only Zanu PF can resolve Zimbabwe's land inequality. With that claim, albeit contradicted by two

17. Financial Gazette, 12 March 1999.

18. After a speculative run in early 1999, it was held at Z\$38/US\$1 until August 2000 when it was revalued at just below Z\$50/US\$1; by early 2001 the black market value was down to Z\$75/US\$1.

19. Cited in Hanlon, 1988: 35.
Radical Rhetoric and the Working Class

decades of land-reform failure, came something else: a memory of an anti-colonial struggle that only Zanu PF can invoke, and an image of a time when the party was in fact a fish within the sea of the rural masses.

Even if there are numerous complex structural relationships in the countryside, the essential problem is simple: land hunger for millions of peasants and small farmers (relegated to the country's worst soils and driest regions), alongside vast unutilised arable land on 4,000 white-owned commercial farms whose products, especially tobacco, are mainly exported. The land question entails many factors: durable colonial/neocolonial relations and deep-rooted white racism; a bad deal struck by the liberation movements with the outgoing Rhodesian regime at the 1979 Lancaster House power-transfer agreement; subsequently a failed market-oriented land reform (and microcredit) program overly reliant upon World Bank money and advice; widespread ruling-party corruption in the land acquisition process; bureaucratic bungling; worsening international commodity market conditions; rising costs of agricultural inputs; devastating (Kuznetsian) cycles of speculative credit and land prices; and growing inequality associated with the disastrous 1990s structural adjustment program.

The gender and generational dimensions of the land question remain extremely important due to residual aspects of colonial-capitalist labour-power reproduction. Consistent with classic systems of 'articulations of modes of production,' many functions-child-rearing, medical care for sick workers and old-age care, without adequate state support-were traditionally farmed out to rural women instead of being internalised within the capitalist labour markets (through adequate state-provided schooling, worker healthcare plans and pensions, none of which were universally available to black Zimbabweans). Although over time, a net positive remittance of wages flowed from urban workers to rural kin and there were some improvements in rural social welfare provision (especially clinics and schools), nevertheless the rural-urban subsidy provided by African women emerged again during the 1990s via transfers of maize and other staple foods to kin in towns and cities. The simple reason was that urban-rural wage remittances declined dramatically due to structural adjustment.

Likewise, environmental pressures associated with land hunger are terribly important. They include not just traditional concerns over woodlot deforestation, soil erosion, watershed siltation, and land exhaustion, but also household environmental problems such as excessive use of wood and paraffin indoors due to lack of electricity (with attendant public health problems), poor quality sources of water and sanitation, and worsening vulnerability to drought and flood.

A central if sometimes unstated presumption in the most rigorous left-nationalist discourse is that these kinds of very durable problems cannot be resolved by mere judicious state intervention, whether via a 1980s World Bank credit plan (in lieu 
of adequate land reform), or the state land acquisition process proposed during the 1990s but only haltingly implemented. Post-colonial history in Zimbabwe and similar settings demonstrates that states, ruling parties, bureaucrats, rich farmers and local power-brokers can and do together resist radical change in rural land, property and social relations. Thus the war vets' invasion of white-owned commercial farms has been promoted by varied Zimbabwean left-nationalists and their allies abroad (including some South African communists, pan-Africanists, landrights activists and other radicals).

More than 1,000 of 3,000 identified white-owned farms continued to witness settlers in the months after the June 2000 election. But given resource shortages of fertilizers, pesticides, marketing support and credit, the sustainability of resettlement operations were rapidly thrown into question. ${ }^{20}$ However, even if unevenly implemented, the occupations and official resettlement exercise had the effect of sobering white farmers (five of whom were killed while contesting the war vets during 2000), and softening their resistance to land reform (many dozens gave up their land to emigrate). The more rational of white farmers conceded that they had not turned over sufficient land to the government for resettlement at Independence (as they were protected by a willing-seller, willing-buyer clause in the transition settlement agreed to at London's Lancaster House). Indeed, in many parts of the country, white farmers professed a willingness to help parcel out chunks of land they weren't using (often estimated in excess of 20 percent of their holdings), and even to persuade selected neighbors who mismanaged their plantations to turn them over for resettlement.

The state, however, already possessed vast quantities of land (once owned by white farmers) which it dud not have the capacity to redistribute. Resettlement on the best land was regularly delegitimised by blatant cronyism and corruption. Another dilemma was the prolific use of good farmland for tobacco, Zimbabwe's main source of foreign currency. When some war vets began tearing up tobacco plants to plant the stable maize crop, they were quickly dissuaded by officials.

20. Lack of support reflected empty state coffers. Indeed, the Zanu PF government had originally pledged to compensate white farmowners for their built improvements (buildings, irrigation and related works), but not underlying land values. However, as land occupations continued and the fiscal deficit rose, that prospect also faded, and the option of Britain coming in to reimburse white farmers for resettled land, as Zanu PF had demanded, was vetoed by the Blair government on grounds, as his aid minister Clair Short unconvincingly explained, that the Labour Party was not the coloniser of Zimbabwe. No compensation was ever discussed for the tens of thousands of (black) farmworkers displaced in the process.
On the ground, the land invasions, assaults and cases of rural intimidation (mostly occurring prior to the June 2000 election, but also during two subsequent parliamentary by-elections) also reflected long-simmering personal grievances that, in this tumultuous political context, reappeared with a vengeance. In addition, argued one former leader of the Zimbabwe African National Liberation Army (now a progressive dissident with the 'Liberators' Platform' group), only approximately 2,000 of the roughly 50,000 war vets were involved in the farm occupations, while most other invaders emerged from the urban lumpenproletariat (they were issued plastic veterans' credentials at Zanu PF headquarters). ${ }^{21}$ There are significant numbers of women occupiers, but just prior to the parliamentary elections they issued a statement expressing dissatisfaction at the control of occupied land and the need for women-headed households to be given at least a quarter of the plots that will subsequently be carved up.

Here the MDC's urban popular and proletarian base proved incapable of widening into the countryside, and especially winning the older generation's support. For the 2000 election, the MDC promised only the establishment of an ill-defined commission to assess who owns what land, how much compensation should be paid for redistribution, and who should be resettled. The overarching MDC rhetoric on land included three points: (a) condemnation of Mugabe and the war vets for opportunism and their use of land as a populist distraction from Zanu PF misrule; (b) concern over the implications of the occupations for farmworkers; and (c) the need to restore the perception of strong property rights so as to provide potential investors with confidence in the rule of law. When shortly after the election, a young MDC MP, Munyaradzi Gwisai, told his urban working-class constituency of the need for radical land reform, Tsvangirai promptly and publicly disciplined Gwisai.

Thus the ruling party could claim a certain degree of success through championing crude, race-based rhetoric, but it was reminiscent less of an inspired nationalist revival and more of the last kicks of a dying horse. The newly-appointed minister of gender, youth development and employment creation announced, for example, 'If you want to work for the government you should be prepared to support Zanu PF. 22 A provincial governor appealed to the public, 'If you see a government car carrying an MDC supporter or a civil servant eating or drinking with an MDC member in a car, confiscate the keys and hand them over to the authorities. ${ }^{23}$ Party loyalty was

21. Interview, Wilf Mhanda, June 2000; for more on the questionable character of Mugabe's claim to nationalist war-hero status, see the interview with Mhanda in Helen Suzman Foundation periodical Focus, December 2000.

22. Border Gezi, quoted in The Daily News, 14 September 2000.

23. Obert Mpofu of Matabeleland North, cited in The Daily News, 8 August 2000. 
paramount, as the country's vice president told a rural rally just prior to the election: 'Even if we put a baboon in Chivi, if you are Zanu PF you vote for that baboon.' ${ }^{24}$ Meanwhile, race relations deteriorated, as reflected in a not atypical comment of a Zanu PF member of parliament:

Let me assure you whites here, that once you support MDC, Zanu PF is not going to treat you as business people, but as politicians. Then if you are treated as politicians, it is like signing your own death warrants. The political storm will not spare you. Let you be informed that our reserve force, the war veterans, will be set on you. ${ }^{25}$

As the main war veterans leader, Chengerai Hitler Hunzvi, confirmed a few weeks before the parliamentary election, 'Like in any revolution, the path is always bloody, and that is to be expected, and hence no one should raise eyebrows over the deaths of four white farmers.... God told us to grab the farms: from them we shall get something to eat. ${ }^{26}$ As for Mugabe's perspective on the farm occupations, 'This is a clear peaceful demonstration and there is no problem with that. ${ }^{27}$

But beyond this more vulgar, intimidating version of nationalism, other conflicting discourses emerged, in relation to international financial pressure. Zanu PF leaders continued talking left (and not necessarily with the intention of acting left) while the MDC talked right. ${ }^{28}$ Asked whether Zimbabwe needed a financial lifeline from the IMF and World Bank, Tsvangirai replied ambiguously, 'I still hate the World Bank and IMF, but I hate them like I hate my doctor.' He explained (in a March 2000 interview) the need for a pragmatic not ideological posture:

They have put us into a serious debt trap. We may have to negotiate with the IMF to get out of that. What is important, down the line, is for Zimbabwe to work itself out of the IMF and World Bank's grip. In the short term, we have to distinguish between financial support that serves Mugabe, versus that which serves the country.

24. Simon Muzenda at an election rally in Chivi, cited in The Daily News, 19 June 2000.

25. Isaac MacKenzie, cited in The Daily News, 23 March 2000.

26. Cited in the Zimbabwe Independent, 19 May 2000.

27. Cited in The Herald, 17 April 2000.

28. The one exception was explained as a slip-of-tongue. Tsvangirai threatened 'mass action' (ordinarily interpreted as non-violent civil disobedience) against the government as the MDC celebrated its first anniversary in September 2000: 'What we want to tell Mugabe today is that please go peacefully. If you don't want to go we will remove you violently.' (The statement was immediately retracted, and the mass-action threat was withdrawn by late 2000, when the limited odds of success became apparent.)
Is it, thus, fair to assert - as does Mugabe's spokesperson, Jonathan Moyo- that 'Tsvangirai is a sell-out' given the MDC's retreat from left rhetoric on land and international financial dependency? Has there been, in short, a fatal penetration of the MDC by capitalist values and personalities?

\section{CAPITALIST ENTRYISM}

Zanu PF's hypocrisy in pointing out MDC capitalist entryism is evident, merely by citing names of tycoons who have nurtured Zimbabwe's ruling party over a quarter-century (Tiny Rowland of Lonrho, Tony O'Reilly of Heinz, mining tycoon Algy Cluff, and others). But quite spectacularly, a leading official of the Confederation of Zimbabwe Industries (CZI), Eddie Cross, was appointed economic secretary of the MDC in February 2000; it was the decisive signal that the core MDC leadership aimed to ally with big business.

Cross comes from a faction of capital that has long supported the introduction of structural adjustment, and which applauded Mugabe for turning to free-market policies during the 1990s. Even after a decade of failure, Cross told the Zimbabwe Independent in May 1999, 'We in industry believe that the only way to make a significant impact is to comply fully with the IMF conditions.' Although in mid-2000, Cross was told to take a backseat role because his public statements were controversial, he is understood to be the central figure pulling the MDC to the right, mediating between the opposition party and its (white) business and commercialfarming funders. The transcript of a speech Cross gave to a packed house at Harare's Book Cafe in March 2000 is one of the few in-depth, honest appraisals of ideological orientation to be found from within the MDC's conservative flank, and is therefore worth substantial attention. ${ }^{29}$

Cross began with a diatribe against the massive state debt accumulated by the Zanu PF regime (there was no mention, until a questioner pointed it out at the end, that the debt was mainly built up as a result of the pro-corporate structural adjustment programme's logic). Cross turned quickly from the critical shortage of forex to the fact that Mugabe is 'totally politically isolated,' with only friends like Laurent Kabila (Democratic Republic of Congo), Sam Nujoma (Namibia), Mahathir Mohamad (Malaysia) and Moamar Qaddafi (Libya)_'providing you don't ask them for money.' He noted the total dependency of Zimbabwe upon one

\footnotetext{
29. Cross' speech, 'Zimbabwe at the Economic Crossroads: Which Way Forward,' contains the quotes below, as reported by this author in Southern Africa Report, 15, 3, June 2000 .
} 
company, British Petroleum (for petrol imports)—but 'you [Mugabe] go and kick them in the teeth. A telephone call to the chairman of BP and we are sunk!'

As for Mugabe's 'Millennium Economic Recovery Programme' (an update of the structural adjustment programme), Cross railed,

It is toilet paper. It is worth nothing. Complete junk and if implemented it would simply compound our problems. They talk about exchange controls, they talk about price control, they talk about continuing to maintain controls on the Zimbabwean dollar. They talk control on wages. But nothing in the document to address the fundamental problems, absolutely nothing. I actually met with the IMF team after they had spent four fruitless days in Harare, going through the document, going through the planning with the Government and everybody that the Government could bring to speak to then-including Bernard Chidzero, the ex-Minister of Finance-to plead with them to reconsider their position. They saw me after the process and said that there was nothing in the document that they could take back to Washington. Nothing. They said if they took that back to Washington they would be the laughing stock of the financial community in Washington. And I am afraid that throughout the financial institutions of the world, Zimbabwe is the black sheep.

Similarly, Cross remarked, the controversial trip to Harare by South African president Thabo Mbeki and several key officials in March 2000 generated very little. A threatened cut to Zimbabwe's electricity supply from SA's Eskom parastatal due to nonpayment was reportedly deferred pending Eskom's takeover of Zimbabwean state facilities, but a US\$120 million loan hinted at by Zimbabwe and widely reported as a bailout in the SA press was hastily denied by the SA Finance Ministry. As Cross interpreted,

South Africa is terrified of our situation here. When Thabo Mbeki was here he agreed to a programme of assistance with Mugabe and he agreed to a wide variety of other things. Went back to Pretoria and the guys in Pretoria said there is no way on this earth that we are going to allow you to prop up their regime in Zimbabwe. He had to go back to the drawing board, as you know. The financial proposals that were agreed to here in Harare were torn up and the South Africans are giving us very limited assistance.

What, then, did Cross propose to resolve the economic crisis?

First of all, we believe in the free market. We do not support price control. We do not support government interfering in the way in which people manage their lives. We are in favour of reduced levels of taxation. We are in favour of introducing Value Added Tax and we will do so quickly, within six months. We are in favour of a National Revenue Authority, these things are things which the government has been talking about for years. We believe they are sound developments. We would like to cap tax levels, both for individuals and for companies.
We would like to reduce the levels of border duties.... The tax burden is simply not sustainable. It is negative in terms of the way it impacts on our society. Now that means we have got to reduce the size of government and not just talk about it.

On privatisation, Cross was especially brash:

We are going to fast track privatisation. All fifty government parastatals will be privatised within a two-year time frame, but we are going far beyond that. We are going to privatise many of the functions of government. We are going to privatise the Central Statistical Office. We are going to privatise virtually the entire school delivery system. And you know, we have looked at the numbers and we think we can get government employment down from about 300,000 at the present time to about 75,000 in five years.

This emphatic agenda was, in effect, the medium-term wish-list of the CZI over several previous years. As Cross reaffirmed, 'There is no doubt in my mind that the only way to grow the economy is on a free-market basis.'

\section{ANTI-CORPORATE POPULISM?}

Yet Cross was not without the sophistication required to work within a party formed by trade unionists. He talked of'a mixture of a highly conservative approach to economics and a strong social emphasis on improving the quality of life for the average Zimbabwean.' Indeed, Rhodesia hosted a peculiar brand of white politics traceable to British working-class immigrants who during the 20th century brought their successful struggle for a generous social welfare state out to the colonies. Confirmed Cross,

My father was an alcoholic and I was raised by a single mom. My mother could not afford to pay school fees and I would not have received an education if the government of Rhodesia had not simply treated me like a special citizen and given me a free education of a very high standard.

At first blush, positive references to the IMF and 'international community' may disguise the fact that historically, this political tradition often contested the interests of foreign capital. Indeed, to hazard a label, Cross became a leading postindependence representative of a relatively patriotic white settler-bourgeoisie. Notwithstanding its British-colonial world-view, the assets of this class are more fully developed and cemented within Zimbabwe than anywhere else, thanks mainly to the 1960s-80s period of rigid exchange controls (a large degree of capital flight occurred in the 1990s, but Zimbabwe remains an extremely comfortable habitat for wealthy whites).

The roots of Rhodesian populism are in intra-white struggle against Cecil Rhodes' British South Africa Company (BSAC), which formally ran the colony 
from 1890-1923. Various factions of the white community expressed such strong grievances-small miners over royalty rights; white unions over wages; settler farmers over their need to block black competition; and the church over social and political relations - that 'self-governing status' was chosen in a 1923 whitesonly vote. In 1933, struggling white farmers, artisans, and civil servants elected a 'left'-sounding (yet very racist) Reform Party under the leadership of Godfrey Huggins. ${ }^{30}$

Huggins promised to rescind BSAC's mineral rights, to impose protectionism, to nationalise key parts of the economy, to provide unemployment relief and white labour rights, and to establish a central bank for the colony. The election was, as Iden Wetherell (1975: 61) observed in his seminal analysis of white politics, fundamentally a populist protest designed to remind the State that its primary consideration lay not with the protection of profit, but with the promotion of institutional safeguards that would insure against a repetition of the recent experience.'

After Huggins drifted towards establishment interests, angry white men reappeared on the political scene in 1962, when Ian Smith led the Rhodesian Front to power. Smith's broad coalition of white Rhodesians included not only those racists fearful of British decolonisation, but others who were adversely affected by the colony's early-1960s economic crisis. Indeed, the 1965 Unilateral Declaration of Independence (UDI), according to Giovanni Arrighi (1973: 367), 'was directed as much against large-scale capitalism as against the Africans. The populist undertones of the UDI campaign were very noticeable.' Those undertones harked back to the 1933 Reform Party victory, Wetherell (1976: 76) insisted, since Smith's intention was undoubtedly to conserve a system of safeguards that the radicals of the 1930s fought so hard to establish....The inheritors of the pre-war populist or "left-wing" legacy [were] now self-defined as "right-wing".

It is this uneasy combination which Cross appears to have inherited. It combines 'conservative' economic policies that meet the needs of the white-dominated business elites, with the memory of state support for a then-white, now-black working class. For even while punting rapid privatisation, the argument Cross makes contains an anti-monopolistic flair:

An MDC government will sell our shares in the Dairy Board [the partially-privatised national milk and cheese marketing board] immediately, use the proceeds to retire debt and we will work actively to encourage competition. What about all the other cozy monopolies? What about Anglo American Corporation and their stranglehold on the sugar industry in Southern Africa? Let us open our border posts....It is competition that will sort out the fat cats in the private sector.

\footnotetext{
30. See, e.g., Gann and Gelfand, 1964.
}

Cross was especially scathing of his CZI colleagues:

They have been too complacent, they have been playing footsie-footsie with this government for too long. They need to be tougher. This Millennium Reform Programme-we see leaders of the private sector saying it is a good programme! It is, well I was going to use a rude word but I won't. It is absolutely nonsense.

Critical of fat cats living off ultra-cheap Zimbabwe labour and acquiescing to Zanu $\mathrm{PF}$ power, Cross adds two additional pillars - corporatist industrial relations and an expanded social plan — to the foundations of the MDC programme:

On the social side we are going to re-visit the issue of minimum wages. Now I am an industrialist and I am well known in industrial circles for actually following this political strategy. I do not believe in low wages. I do not believe in an industrialist or anybody else being allowed to pay wages which are well below the basic cost of living in cities.... So we will, as a Government, and with the private sector through a social contract, and working with the trade unions and employers, work towards a situation where we will pay much higher wages in industry, even if it means losing jobs, so that people working in the cities will be able to afford to live in those cities on a whole family basis. He will be able to send his children to school, he will be able to rent or own accommodation which means he can live there with his entire family. For us that is fundamental.

In addition to attacking that [migrant labour] system with everything at our disposal' - in part because of migrancy's contribution to the spread of AIDSCross set out impressive social promises:

Education is the key and seven years of compulsory free education-free education-and free, not in the way we are doing it at the moment [with parent fees]. We mean free, parents will not be required to pay for it. And you ask, 'Can we afford that?' Yes, we damn well can, we damn well can! And the international community has the resources to help us build that system and they are willing to do so.... We have a programme for housing - we are going to give tenure, freehold tenure, to everybody who holds tribal trust land leases, immediately we come to power.. The government has been talking about this for the past ten years, we are not going to talk about this, we are going to do it and we are going to fast-track the administration procedures through massive housing schemes, to provide siteand-service schemes in all our cities for the entire backlog of housing within five years. And you say, ‘Can we afford to do it?’ Yes, we can! Yes we can, and the international community is prepared to help us with a programme like that....We have got to have primary health care throughout the country. We have got to get our hospitals back on their feet.... Our social programme is going to be strong and it is going to be dynamic and it is going to be directed at the absolute poor, and there's no compromising that. We are totally committed to that, and you need to know it - this is not a rhetorical commitment, this is not a party of the 'haves,' this is not a party on the gravy train. 
Beginning around 1990, Zimbabwe's have-nots were ferociously pummeled not only by Mugabe and his then labour minister John Nkomo-who tried often enough to fracture the trade union movement-but by the IMF and international community. Here arises the central contradiction. Cross, ironically, now implies that his own ticket to the MDC dance is IMF access.

This leads to the obvious question: what is, and will be, the balance of power within the MDC when the obvious choice between free education and free markets must be made? That will be the real crossroad. To his credit, Eddie Cross is transparent about his agenda. But it will be up to the MDC's left-leaning populists, not populists who distortedly echo questionable traditions, to better represent the needs of Zimbabwe's black povo (multitudes).

\section{CONCLUSION}

This article has laid bare some of the core contradictions associated with diverse forms of political rhetoric in Zimbabwe, including radical arguments by presumed 'left nationalists' and presumed pragmatic arguments by MDC economic conservatives, and has found them both wanting. The resolution to this confusion can only be found at a deeper, structural level.

At the outset, we argued that in a situation lacking effective socio-economic equilibrating mechanisms, a force whose logic is external to the prevailing systematic logic must be invoked to establish the conditions required for the system's restoration. The logic of capitalism is based on accumulation, growth and expansion of markets. During a typical capitalist crisis, the external counterforce is typically a variant of recession, depression and 'devaluation,' i.e., a process in which there is a write-off of economic 'deadwood'-overcapacity in plant and equipment, excess unemployed labour power, crashes in the value of financial assets (including via inflation) and the like. The corresponding resistance by poor and working people, environmentalists and women, indigenous movements and other oppressed people, slows down or moves the devaluation around. But truly resolving the crisis for a new round of capital accumulation occurs only with sustained restructuring of economic and social relations.

I have argued elsewhere that such devaluation and resistance characterised Zimbabwe's history during several crucial periods: the 1890s, late 1920s-30s, and late 1950s-60s (Bond: 1999a). In contemporary Zimbabwe, the 1970s overaccumulation crisis and the devaluation process - and necessary shift in racial/class relations-began in earnest during the late 1970s, continued through the 1980s notwithstanding a minor stabilisation of the social wage, resumed again in the early 1990s, and accelerated with a vengeance from late 1997 through the present.

But there has been something extremely unusual about Zimbabwe's recent experience. The more the devaluation has hurt prospects for social development, the more that a desperate Robert Mugabe conjured up radical rhetoric to outflank the alienated working class on its left. Zimbabwean nationalism's 1990s exhaustion had the unintended consequence, perhaps, of re-radicalising official discourses. Yet by the time Mugabe realised how disastrous his Washington-designed policies were for the masses, in late 1997, it was too late.

From this ideologically-muddled situation, we simply learn, yet again, that economic conflict generates political and social strife, in the course of any period of crisis management and displacement - and that as a result, class configurations and alliances potentially shift very rapidly. The outcome can never be certain, for no matter how much left-wing rhetoric is invoked, the real practical activity of the state can just as easily bolster the interests of capital, as happened through much of the past decade under the banners of Esap and Zimprest.

But perhaps this lesson has not yet been learned, for what is disturbing about the contemporary Zimbabwe crisis is that notwithstanding further sharp rounds of dramatic devaluations, with worse to come in subsequent months and years, virtually none of the major social forces have moved from populist rhetoric about who is to blame for the malaise. There is no hint, yet, of more fundamental questioning as to whether Zimbabwe can, indeed, 'develop' and grow in the context of a world economy also in the throes of crisis management and displacement.

It is here that the coming period of hot contestation over macroeconomic policy becomes crucial. Zanu PF leaders will be more accommodating to neoliberalism, out of desperation for an IMF/World Bank fix. The MDC's more pro-business faction (centered around Cross) will, with Tsvangirai's permission, will probably continue to outmaneuvre leftwing influences within the opposition party. But that is not the end of the Left's influence. A variety of 'civil society' groups-thinktanks and non-governmental organisations with sophisticated, progressive leaders, including church agencies, a resurgent movement of residents' associations, and the more progressive currents within the $\mathrm{ZCTU}^{31}$ itself-have established a broadly anti-neoliberal perspective.

The post-election launch of the Campaign Against Neoliberalism in Zimbabwe-led by young church-based activists well connected in the international social-justice movement-was one hopeful premonition of this current. Another example was the joint budget statement ("Civil Society Position on Minimum

31. Given the ZCTU's importance within the MDC, it was only a matter of time before Zanu-PF began to poach. According to one reliable report (Daily News, 17 November), Sources insisted that there is serious division in the ZCTU between pro-Zanu PF and pro-MDC factions in the leadership of the ZCTU....Sources in the ZCTU said the composition of a new executive would hinge on the political leanings of 
Standards of a Democratic Budget Process') issued in November 2000, by the Combined Harare Residents Association, Community Working Group on Health, National Association of Non Government Organisations, National Council for Disabled Persons of Zimbabwe, Public Services Association, Zimbabwe Coalition on Debt and Development, Zimbabwe Council of Churches, Zimbabwe Congress of Trade Unions, Zimbabwe National Chamber of Commerce, Zimbabwe Teachers Association, Zimbabwe United Residents Association, and Womens Action Group. ${ }^{32}$ This is the core group of social forces that will attempt to keep the MDC honest.

What will these and various other more local organisations be debating in the period prior to the 2002 election? No doubt, ongoing conflict can be expected on major constitutional, racial and health-related issues (as AIDS continues to worsen). But what might also transpire, to be welcomed by progressive campaigners, is an increased public consciousness over the merits of Washington-approved economic policy.

the leaders of each of the 33 trade unions that make up the labour body....The ZCTU official newspaper, The Worker, in its October/November edition quoted unnamed sources alleging that the ruling party is clearing subscription arrears of trade unions sympathetic to the party to influence them to vote for a leadership loyal to it. Only paid up unions have voting rights.

Both the current ZCTU executive and general council are made up mainly of MDC executive members who include Isaac Matongo, Nicholas Mudzengerere, Gift Chimanikire, Remus Makuvaza and MDC members of parliament Thokozani Khupe, Esaph Mdlongwa, Gilbert Shoko, Pauline Gwanyanya, Melfort Gwetu and Bethel Makwembere.

At least of the 10 of the 33 affiliate unions that make up the ZCTU have leaders who are believed to be sympathetic to Zanu PF while the rest are reportedly pro-MDC. This week sources close to the ZCTU said Matongo is tipped to become the president of the labour movement ahead of currently acting secretary-general, Isodore Zindoga who is also believed to be eyeing the same post. Zindoga has denied any links with the ruling party, telling The Worker that he is an 'undiluted trade unionist' who 'does not mix trade unionism with politics.'

32. The groups' statement began,

The current budget process is deeply flawed. This is a major reason for the mounting public dissatisfaction over the way public priorities are reflected in the national budget and over the manner in which expenditures are managed. Persistent economic decline, weak redistribution of economic opportunity, ad hoc expenditure decisions, inadequate funding of social sector obligations and weak parliamentary control over spending have all combined to undermine the critical role of the budget as an instrument of public policy.

While by no means radical, this perspective does at least shy firmly away from promoting fiscal contraction, which is a core goal of the MDC's business supporters.
Elite opinion-makers seemed to sense this coming conflict as well, and by early 2001, two columnists of the influential Zimbabwe Independent argued the merits of neoliberalism with rhetorical antagonism designed, it seemed, to nip any dissent from orthodoxy in the bud. Wilbert Mukori scornfully recalled 'Tsvangirai's ZCTU days' when the trade union movement's economic policies were at best a confused rehash of Zanu PF's socialist trash....The MDC would best be advised to adopt whatever revision of the Esap the IMF/World Bank has to offer. ${ }^{33}$ And the country's main business commentator (an accountant, Eric Bloch), defended that failed strategy on (transparently faulty) grounds that

Esap was, to a very great degree, implemented only as a matter of lip-service.

Esap Government had no substantive commitment to, or conviction in, Esap and therefore only implemented the programme partially. Patients who take prescribed medication erratically, inadequately and in disregard for the prescription directions, rarely recover....It is government which alienated IMF support, and also that of most international monetary organisations, the support of donor nations, and the support of aid agencies. ${ }^{34}$

But elite consensus is not capable of submerging more profound socio-economic contradictions. At least ten arenas of strife have emerged-or soon will-between the IMF/World Bank agenda and the Zimbabwean society (in a rough order of importance): the enormous budget deficit; land redistribution; price controls; wage restraint; financial and monetary management; the value (and technique of formal pegging) of the Zimbabwe currency; the ability of the state to maintain foreign currency controls (through restricting corporate forex accounts); luxury goods import taxes; pressure on the state to privatise; and the emerging regional free-trade regime propelled by South Africa. ${ }^{35}$ These arenas, as well as others still to emerge, will require of any political force in Zimbabwe a coherent programme; the IMF and its local ally Cross (with the CZI), have such a programme.

We might conclude with the observation that in Zimbabwe, like so many other sites of struggle on the semi-periphery and periphery of the world economy today,

33. Zimbabwe Independent, 12 January 2001.

34. Zimbabwe Independent, 12 January 2001.

35. By way of evidence, an IMF study of Zimbabwe in late 2000 insisted that for Zimbabwe to regain access to borrowing rights,

Fiscal consolidation and exchange rate re-alignment-the main pillars of the proposed package-should be buttressed by a re-orientation of public spending to priority sectors, tight monetary and wage policies, and expedite structural reforms especially privatisation, civil service reform and trade liberalisation.

The state-owned Herald (9 December 2000) newspaper reported that government, in response, had decided that 
the challenge is to pull together both social and political movements that forthrightly contest neoliberalism. Any review of merely the year-long period following the Seattle protest of December 1999 reflects this global upsurge. The sabotage of a new Seattle Millennium Round of the World Trade Organisation was caused not only by diverse activists on the street, but also, inside the summit, by African governments (led, interestingly, by Zimbabwe's then trade and industry minister, Nathan Shamuyarira, who subsequently retired from government while continuing to serve Zanu PF as information officer). Seattle bolstered radical social and labour movements across the world, and was soon echoed in more than a hundred other sites of struggle both North and South.

Is there any connection to the confused politics of radical rhetoric and dying nationalism in Zimbabwe? For many alienated Northern youth who represented the majority of protesters at Seattle, Washington, London, Melbourne, Prague and Nice during 2000, the anti-neoliberal protests were a logical outgrowth of discrete, anti-corporate campaigning (Klein, 2000). But for Southern social and labour movements, the opportunity had arisen for transcending the mere IMF Riot as knee-jerk protest, and increasingly bringing out mass activist responses with programmatic demands. In some instances, particularly in Latin America (Bolivia and Ecuador), the anti-neoliberal activism reached a near-insurgent stage; in other sites (South Africa, Nigeria and India), many millions of workers became involved in

Fiscal consolidation would be achieved by reducing the budget deficit from an estimated 23 percent to 15.5 percent of the gross domestic product in the 2001 national budget presented by $\operatorname{Dr}$ Simba Makoni last month. The deficit would be curtailed to 8 percent in 2002 and 3 percent in 2003. The wage bill will also be limited from 16.7 percent to 12 percent of GDP, which refers to the total value of goods and services produced in Zimbabwe, through the rationalisation of the civil service....Zimbabwe is also in the process of eliminating foreign currency and exchange restrictions, stimulate the export sector, paying of its debts and improve the collection of statistical data.... But the IMF remained saddened by slow progress in rationalising the civil service and disposing of Government stake in public enterprises.

In early 2001, another IMF report was partially leaked, emphasising the need for devaluation. According to the independent press (Zimbabwe Independent, 5 January),

The International Monetary Fund has urged the Reserve Bank of Zimbabwe (RBZ) to scrap its monetary policy linking rates of interest with the rate of inflation, effectively pegging the bank rate at between 2 to 2.5 percentage points above the rate of inflation. However, the RBZ has been commended by the IMF for its decision, which has not yet been announced in the country, to depart from a fixed exchange rate system.... The local dollar, fixed at 38 to the US unit for 19 months until it was devalued to 50 against the greenback in August last year, is currently trading at 55 against the US dollar. However, it is trading at 70 on the parallel market, which has been active since the controls came into effect. mass strikes against neoliberalism; in yet other protests (South Korea, Argentina, Turkey), tens of thousands of protesters took to the streets in waves of militancy. ${ }^{36}$

Are enough Zimbabweans aligned with these more radical challenges to orthodox economic policies, to make a difference to their own country's future? Or are radical rhetoric and ideological confusion associated with the exhaustion of both African nationalism and Zimbabwe's capital accumulation cycle going to close the current window of opportunity for progressive social change?

One scenario worth posing for Zimbabwe's Left is the (risky) possibility associated with taking advantage of the country's coming misfortunes. As the worsening crisis unfolds, macroeconomic management will be increasingly remote-controlled (or at least strongly influenced) from Washington; enormous strife will continue over shortages and rising inflation on basic needs goods, ranging from bread to transport to paraffin; debt relief will not be forthcoming; attempts to forge a social contract in this environment will be fruitless; the Mugabe regime will desperately hand out patronage to maintain some semblance of unity within Zanu PF; more confrontations will occur between security forces and MDC supporters (as witnessed in a tragic July 2000 soccer match stampede and in the army's use of force to quell October 2000 urban protests over price increases); paramilitarism will intensify on the part of war veterans and others (e.g., by-election intimidation and the bombing of the main daily newspaper in January 2001); and further 'mass action' calls will be made by the left-leaning elements in the MDC. ${ }^{37}$

But this likely period of conflict can only be turned to advantage by the Zimbabwe Left if the surface-level confrontations above are linked to the nearimpossible conditions for managing semi-peripheral neoliberalism more generally, and if a 'People's Development Charter' strongly advocated for by the working-class movement can sway society in general and the middle-class leadership of the MDC in particular. Key points will have to be contested, such as the struggle over price controls (a short-term palliative to be sure, but a popular band aid to some of the inflationary problems); foreign exchange controls; repudiating Mugabe-era debt mainly on grounds that IMF/Bank programmes were incompetently designed; massive expansion and redirection of basic-needs state subsidies (e.g. of water and electricity prices) to low-income households; growing state ownership and worker control of important-and potentially viable-bankrupt private firms (and mines and farms); and a reorientation of budgetary spending and imports towards

\footnotetext{
36. See documentation by the World Development Movement: http://www.wdm.org.uk/cambriefs/DEBT/unrest.htm; see also Bond forthcoming-b for
} analysis.

37. See the 'Suharto Scenario' as painted in Alexander, 2000. 
working-class and poor people's needs. As it stands, virtually all of these logical social demands are likely to be rejected by Washington's Zimbabwe managers; in turn, they would gain a certain degree of resonance amongst left-nationalists in Zanu PF, and unequivocal hostility within the MDC's neoliberal flank. (A complicating factor is the likelihood of US sanctions against Mugabe-via a resurrected Zimbabwe Democracy Act in the US Congress-which some militants in the MDC support, to the consternation of the bourgeoisie and petit-bourgeoisie, who will most feel its effects.)

On the one hand, such a programmatic challenge risks yet more confusion ahead. Zanu PF may try even harder to turn populist rhetoric into mass support; however, popular disgust with the Mugabe government amongst urbanites and more sophisticated rural residents (led by teachers) is not likely to wane, not even if Makoni is made heir apparent. On the other hand, by returning to more confrontational programmatic struggles - in parliament, in various other venues of advocacy, in street protests - the progressive forces in and around the MDC will very likely pull the 2002 presidential campaign debate to the left. That, in turn, will clarify to the masses which politician-Tsvangirai or whomever Mugabe anoints-is best placed to address the more profound conflict over Zimbabwe's economic future. And forceful advocacy of a left-programmatic strategy will more rapidly weaken not only the power of the neoliberal elements within the MDC, but within Zimbabwean society more generally, as well as in relation to the financial-technical hold of Washington over Harare. (Prospects for this course dimmed markedly in late 2000, when the MDC executive rejected the militants' call for a holiday-season massaction campaign, on grounds that it was too dangerous given Mugabe's monopoly on violence.)

What would happen if the MDC took this kind of political turn-away from a post-nationalist neoliberalism, to post-neoliberalism? If the organic Left won sufficient hearts and minds of society and leading politicians, and in doing so overwhelmed the residual elites of Zanu PF and the bourgeois alliance between Harare big business and Washington, what options might then emerge? If power were decisively transferred in 2002, could Zimbabwe indeed embark upon a more inwardoriented, basic-needs strategy, as mandated in the February 1999 Working People's Convention?

No, argues Eddie Cross forcefully, There Is No Alternative to Esap, Zimprest and their structural adjustment successors. In early 2000, in order to get roughly US\$2 million worth of campaign resources from wealthy donors (in Zimbabwe and abroad), Morgan Tsvangirai seemed to agree. But this is by no means his permanent perspective (witness Tsvangirai during the late 1980s-early 1990s). Robert Mugabe, meanwhile, contests the moral and political acceptability of such power relations, but still offers nothing to change power relations or even the technical management of the economy. The reign of Simba Makoni as finance minister will not change matters. Social movements will observe such disarray, once their programme is popularised, and understand better the hopelessness of proceeding along any of the trajectories suggested by the orthodox political and economic leaders.

Does this pessimistic account of Zimbabwean politics partially justify the conclusion of Hardt and Negri, that sovereignty 'is losing effectiveness,' and with it, so too fades 'the autonomy of the political'-and likewise, so evaporates any hope that left-wing social forces can one day take and reorient their nation-states? While Cross and Makoni might answer in the affirmative, Mugabe has himself refused to accept this conclusion. But to the detriment of his constituents, Mugabe's manipulation of state sovereignty has, for two decades, engendered corruption, mismanagement, authoritarianism and a venal politics that reduces to hysterical nationalism that, as Archbishop Desmond Tutu commented prior to the June 2000 election, leaves the president looking like a 'caricature of an African leader.'

At the level of political fundamentals, there must be an alternative approach. Optimistically, Boris Kagarlitsky (2000: 39) posits that since 1998, capitalist crisis has

forced even the neoliberal mainstream to change its attitude towards the role of the state. Experts of the IMF suddenly declared that 'certain types of capital controls may be justified in some circumstances.' American businessmen agreed: 'Maybe some sort of protectionism makes sense for Russia.' The state must use its strength to overcome the crisis of the market. 'If that means instituting wage and price controls, or renationalizing basic industries to ensure supplies and employment, so be it.

To be sure, Kagarlitsky also advocates international regulation but correctly concludes that

no international regulation will work unless it is based on national and regional bodies. If it is not, the rules and decisions made by international bodies simply will not be implemented. And no democratisation of international relations is possible without democracy at the level of a nation state.

I agree with that sense of priority - i.e., capturing, democratising and retooling the nation-state, which in turn entails rejection of international neoliberal policy pressure. What is advocated is no return to nationalism (even if it is apparently important for Sibanda to debunk Zanu PF's deformed, exhausted nationalism with a class-oriented 'chimurenga' discourse), but instead, a firm restatement of the need to rebuild national sovereignty (and later, regional coordination) ${ }^{38}$ If this is an

38. South African subimperialism will first have to be overcome, through regionalismfrom-below; see Bond, Miller and Ruiters, 2000. To this end, Samir Amin (1999: 77) 
appropriate way forward, Zimbabwe's social movements can also take confidence from previous episodes of tough macroeconomic management throughout the country's history. Concrete strategies included imposition of watertight exchange controls; careful reflation of the economy through strategic state spending; prescribed assets on financial institutions; increasing nationalisation of strategic sites of the economy; directed investment requirements; creative juggling of import/export requirements; default on outstanding foreign debt; and a more general commitment to 'get the prices wrong,' if need be, to assure maximum local backward/forward linkages. The last two times such policies were adopted, during the 1930s and just after the Unilateral Declaration of Independence was declared in 1965, the Zimbabwean (then Rhodesian) economy grew at nearly double-digit rates each year for a decade (Bond, 1998: Chapters Two and Five).

On those occasions, growth through partial-delinking occurred in a way that amplified racial, gender and class divisions. Assuming the political balance of forces can be changed in coming years, it should be even more feasible, technically, to impose the same mechanisms but this time, to reorient production to meet basic needs, particularly of rural women, and particularly in areas that should be easy to expand-rural water/sanitation and small-scale irrigation systems, electricity, public works - without debilitating import requirements.

These are probably the minimal policy arrangements in the sphere of national political-economy required for Zimbabwe to prosper as a society. At the international scale, reduced pressure from neoliberal actors and markets will also be vital (as demonstrated repeatedly by visiting IMF missions). Fortunately, this is being achieved increasingly through initiatives ranging from mass protests in Seattle, Washington and Prague, to more surgical activist campaigns (such as that which forced the IMF and World Bank to cease imposing user-fees in health and education programmes in October 2000). ${ }^{39}$

In Zimbabwe, there appears only one set of social forces capable of moving in this direction: the radical component of the MDC and its civil society allies. Time will soon tell if they have begun this march, or remain in the cul-de-sac in which most radical rhetoric has left the beleaguered Zimbabwean working class.

suggests 'regionalisation aiming at the building of a polycentric world,' in part grounded in 'grassroots labour-popular social hegemonies. ${ }^{138}$. South African subimperialism will first have to be overcome, through regionalism-from-below; see Bond, Miller and Ruiters, 2000. To this end, Samir Amin (1999: 77) suggests 'regionalisation aiming at the building of a polycentric world,' in part grounded in 'grassroots labour-popular social hegemonies.'

39. The most interesting tactic aimed at weakening international financial determination of nation-state development prospects is the World Bank Bonds Boycott: http:// www.worldbankboycott.org

\section{REFERENCES}

Ake, C. (2000). The Feasibility of Democracy in Africa. Dakar: Codesria.

Alexander, P. (2000)."The Zimbabwean Working Class, the MDC and the 2000

Election." Paper presented to the Rand Afrikaans University Department of Sociology Zimbabwe Seminar, Johannesburg. 28 July.

Amin, S. (1999). "Regionalization in Response to Polarizing Globalization." in B.Hettne, A.Inotai and O.Sunkel (Eds). Globalism and the New Regionalism. London: Macmillan.

Arrighi, G. (1973)[1967]. “The Political Economy of Rhodesia.” in G. Arrighi and J. Saul, Essays on the Political Economy of Africa. New York: Monthly Review.

Bond, P. (1998). Uneven Zimbabwe: A Study of Finance, Development and Underdevelopment. Trenton: Africa World Press.

Bond, P. (1999a).“Zimbabwe’s Political Reawakening.” Monthly Review. 50: 11.

Bond, P. (1999b). “Global Economic Crisis: A View from South Africa.” Journal of World Systems Research http://jwsr.ucr.edu/. 5: 2 .

Bond, P. (forthcoming-a)."Economic Strategy for a Post-Nationalist Zimbabwe: Outward versus Inward Orientation." in Journal of Southern African Studies.

Bond, P. (forthcoming-b). "African Grassroots Roles in the 'Anti-Globalisation' Movement." in G.Kohler (Ed). Globalization and Resistance. New York: Nova Press.

Bond, P. D.Miller and G.Ruiters (2000)."The Southern African Working Class: Production, Reproduction and Politics." in L.Panitch and C.Leys (Eds). Socialist Register 2001: The Global Working Class at the Millennium. London: Merlin and New York: Monthly Review Press.

Gann, L. and M. Gelfand (1964). Huggins of Rhodesia. London: Allen and Unwin.

Hanlon, J. (1988). "Destabilisation and the Battle to Reduce Dependence." in Colin Stoneman (Ed). Zimbabwe's Prospects. London: Macmillan.

Hardt, M. and T.Negri (2000). Empire. Cambridge: Harvard University Press.

Kagarlitsky, B. (2000). The Twilight of Globalization: Property, State and Capitalism. London: Pluto.

Klein, N. (2000). No Logo. London: Flamingo.

Mamdani, M. (1996). Citizen and Subject: Contemporary Africa and the Legacy of Late Colonialism. Princeton: Princeton University Press.

Mandaza, I. (1986). “The Post-White Settler Colonial Situation.” in I. Mandaza (Ed). Zimbabwe: The Political Economy of Transition, 1980-86. Dakar: Codesria.

Mhone, G. and P.Bond (forthcoming). "Botswana and Zimbabwe." in M.Murshed (Ed). Small Economies and International Vulnerability. Oxford: Oxford University Press.

Mkandawire, T. (1984)."Home-Made' (?) Austerity Measures: The case of Zimbabwe." Paper presented at seminar on Austerity Policies in Africa: Under IMF Control. Dakar, Senegal. 19-21 June. 
Murapa, R. (1977).“Geography, Race, Class and Power in Rhodesia.” Working Paper, Council for the Development of Economic and Social Research in Africa. presented at the Conference on the Special Problems of Landlocked and Least Developed Countries in Africa. University of Zambia, Lusaka. 27-31 July.

Raftopoulos, B. and L.Sachinkonye (forthcoming). Zimbabwean Labour since Independence. Harare: Weaver Press.

Sachikonye, L. (1998).“Trade Unions: Economic and Political Development in Zimbabwe since Independence in 1980." in B.Raftopoulos and I.Phimister (Eds). Keep on Knocking. Harare: Baobab Books.

Wetherell, H.I. (1975).“N.H. Wilson: Populism in Southern Rhodesia." Rhodesian History. 6.

Wisner, B. (1991). Power and Need in Africa. London: Earthscan.

World Bank (1982)."Report and Recommendation of the President of the IDA to the Executive Directors on a Proposed Credit in an amount equivalent to US\$1.2 million to the Government of Zimbabwe for a Petroleum Fuels Supply Technical Assistance Project." Energy Division, Eastern Africa Regional Office. Washington, DC.

World Bank (1995). Project Completion Report: Zimbabwe: Structural Adjustment Program. Country Operations Division. Washington, DC.

Yeros, P. (forthcoming). Labour Struggles for Alternative Economics in Zimbabwe: Trade Union Nationalism and Internationalism in a Global Era. Southern African Political Economic Series Monograph Series. Harare.

Zimbabwe Congress of Trade Unions (1996). Beyond Esap. Harare. 